Article

\title{
Financial Reforms and Financial Fragility: A Panel Data Analysis
}

\section{Syed Faizan Iftikhar}

Applied Economics Research Centre, University of Karachi, Karachi 75270, Pakistan;

E-Mail: faizanburney@hotmail.com or faizanburney@aerc.edu.pk; Tel.: +92-21-99261541-49 (ext. 232)

Academic Editor: Nicholas Apergis

Received: 12 March 2015 / Accepted: 15 April 2015 / Published: 24 April 2015

\begin{abstract}
This paper explores the relationship between financial reforms, financial liberalization and the quality of banking regulation and supervision for financial fragility by applying a dynamic two-step system generalized method of moments GMM panel estimator technique. The finding of this study is that the financial vulnerability of the banking sector could be affected, not only by bank-specific and macro-specific variables; but also by financial liberalization and banking regulations and supervision policies. The empirical results of this study confirm the evidence that financial reforms and financial liberalization significantly enhance the likelihood of financial fragility while strong banking regulations and supervision have an inverse relationship with financial fragility. The results of this study also explain that the lag value of loan growth and unemployment contribute to enhancing financial fragility while equity to assets ratio, natural log of total assets and share of foreign banks reduce financial vulnerability.
\end{abstract}

Keywords: financial fragility; financial liberalization; banking regulations and supervision; two-step system GMM

JEL Classification: C23; G21; G28

\section{Introduction}

Over the last several years, increasing financial liberalization, integration into the international financial markets, technological advancement, and rapid development of new financial products, and increasing competition in the banking sector have become an important challenge in shielding financial 
stability in the current global financial system. The recent financial crisis all over the world, which was initiated in the US, was preceded by a high level of Non-Performing Loans (NPLs). Due to this, the international financial system needed substantial bail-outs to avoid any further large collapses of the banking sector (See Koutsomanoli-Filippaki [1]; Moshirian [2]).

Until recently, most research studies have investigated the determinants of NPLs by using either the bank-specific or country-specific variables (or both). Guy and Lowe [3] examined the problem of NPLs in the Barbadian banking system by using bank and macroeconomic variables during the period 1996-2010 and suggested that both the bank-specific and macro-specific variables are equally important in recognizing the behavior of NPLs. They applied various macroeconomic shocks on the Barbadian banking sector and found high NPLs under different macroeconomic stresses. ${ }^{1}$ Moreover, Fofack [5] studied the main factors of high NPLs in Sub-Saharan African countries during the 1990s and found a strong correlation between the NPLs and economic growth, real exchange rate appreciation, real interest rate, interbank loans and the net interest margins; these results also highlight the importance of micro and macro-specific determinants. Shehzad et al. [6] similarly used the data of 500 banks from more than 50 countries, during the period 2005-2007. They suggested that ownership concentration has a negative effect on banks' NPLs, if that share of ownership is more than $50 \%$.

Similarly, along with the bank specific variables, another strand of the literature has also highlighted the relationship between macroeconomic variables and the NPLs. Louzis et al. [7] examined the influence of macroeconomic variables on NPLs in the Greek banking sector by using dynamic panel data. They further explained that NPLs can be described by macroeconomic variables, such as, real GDP growth, unemployment, interest rates and public debt; and found strong effects of these macroeconomic variables on NPLs. Their findings also suggested that management quality and inefficiency may be considered as important indicators for future NPLs. Festic et al. [8] studied five new European Union (EU) member states and revealed that the amount of available finance and credit growth may impair banking performance and worsen NPLs due to overheating of economies. Similarly, Espinoza et al. [9] studied the link between macroeconomic variables and NPLs of 80 individual banks in the Gulf Cooperative Council (GCC) countries. They suggested that high rates of NPLs are generally attributed to high interest rates and the adverse macroeconomic conditions. Moreover, other studies, for example Boudriga et al. [10,11]; Berger and Boye [12]; Rinaldi and Sanchis [13]; and Ranjan and Dhal [14] also include macroeconomic determinants as an explanatory variable of NPLs. $^{2}$

This paper goes beyond these studies by considering the financial reforms, financial liberalization and banking regulation variables as determinants of financial fragility, along with both the bank-specific and macro-specific variables. ${ }^{3}$ However, Demirguc-Kunt et al. [16,17] examined the relationship between financial liberalization and banking crises, in their pioneering study, and suggested that probability of banking failure is very high in financially liberalized system. The most closely related

1 Another study by Salas and Saurina [4] includes both microeconomic and macroeconomic variables as determinants of NPLs in the Spanish banking system. They also suggested that any future change in NPLs can be highly identified by bank-specific variables in the saving banks than the commercial banks.

2 Shen and Chen [15] also used GDP growth in his paper and found that growth has a significant negative effect on NPLs.

3 Surprisingly, only a few studies investigate the effect of bank specific and country specific variables on NPLs. 
papers to my study are Delis [18] and Hermes et al. [19]. For example, Delis [18], estimates the impact of financial reforms and the quality of institutions of banks in 84 countries of the world. Delis found that financial reforms policies have a significant impact on banking competition and reduce the market power of banks, especially in developed economies where institutions are advanced, while this importance diminishes and does not improve banking competition in countries where institutions are fragile and not functioning well. Similarly, Hermes et al. [19] examined the impact of financial reform on the bank efficiency of 41 countries. They also measure the impact of financial liberalization and banking regulations on banks' efficiency. To calculate bank efficiency, they applied a stochastic frontier analysis approach at the individual bank level and found that financial liberalization policies have a significant and positive impact on banks' efficiency.

The theoretical perspective about the financial liberalization is that financial liberalization enhances the efficiency of financial system. While, on the other side it raises the intensity of competition in the financial system. This high competition erodes profitability of financial institutes and leads to financial fragility. So, this paper inquires whether financial liberalization enhances financial fragility. The objective of this paper is to explicitly explore the link between financial reform and financial fragility in sample countries by applying a dynamic two-step system GMM panel estimator technique. Consequently, this study examines whether financial reform policies reduce or increase financial fragility of the sample countries. ${ }^{4}$ Moreover, the main aspect of this study is to analyze the relationship of both the financial liberalization policies and the quality of banking regulations and supervision on financial fragility. It is investigated whether the effect of financial liberalization policies on financial fragility of the banking system is conditional on the quality of banking regulation and supervision.

This study aims to contribute to the existing literature of NPLs in two different ways. First, using the sample of a multi-country bank-level dataset, provided by Fitch/IBCA/Bureau Van Dijk, of 76 developed and developing economies, based on 779 banks over the period 2001-2005. Second, along with the financial reform variable, the study also examined the impact of financial liberalization and the banking regulations and supervision index, individually, on financial fragility by utilizing the new index of financial reform. The index of financial reform contains comprehensive information on the different sub-indexes of financial reform policies which also enables us to see how these policies may affect banks' effectiveness at a country level.

The organization of this paper is as follows: a brief discussion of data and definitions of the variables are described in Section 2; the empirical model of financial fragility is explained in Section 3. The empirical findings are reported in Section 4, while the summary and conclusions of this study are provided in Section 5.

\section{Data Sources, Financial Fragility and Determinants of Financial Fragility}

\subsection{Data Sources}

The data of bank-specific and macroeconomics-specific variables has been obtained from different sources. The data on bank-specific variables included: impaired loans to gross loans (a proxy for financial fragility), cost to income ratio (a proxy for bank efficiency), equity to assets ratio, growth of

\footnotetext{
4 A list of the countries is available in Table 1.
} 
gross loans and a logarithm of total assets. These have been obtained from the Bank-scope database maintained by Fitch/IBCA/Bureau Van Dijk. The data of ownership of foreign banks and government banks is also extracted from the Bank-scope data set. For macroeconomic-specific variables, such as, GDP per capita growth, GDP deflator and unemployment rates, the data of these variables has been taken from the World Development Indicator (WDI), while the financial reforms data is attained from the "New Database of Financial Reforms" developed by Abiad, Detragiache and Tressel [20]. ${ }^{5}$ The selection criteria of sample countries in this paper are also based on Abiad et al. [20] data set, which contain 91 developed and developing countries. In this paper, we consider only those countries which have minimum five and maximum 300 banks. We do not include countries like US, UK, Germany, Italy, France, Switzerland, Spain, Canada, Australia, Austria, Korea and Sweden, because the number of banks in these countries are 22,081 out of 30,634 which may capture the impact of financial reforms on financial fragility in other countries. The description and construction of all variables have been provided in the next section.

\subsection{Financial Fragility}

"In macroeconomics, the term financial fragility is used loosely to refer to a financial system's susceptibility to large-scale financial crises caused by small routine shocks" [21] (p. 220). In this study, we have employed impaired loans (the accounting term for NPLs) to gross loans used as a proxy for financial fragility. ${ }^{6}$ The ratio of impaired loans to gross loans is defined as the amount of loans which are impaired or doubtful. This measure explains that the higher (lower) the ratio, the lower (better) the asset quality is (see Appendix Table A1). Shen and Chen [15] used NPLs as a proxy of banking fragility, while Shehzad et al. [6] considered impaired loans to gross loans as an indicator of bank riskiness.

\subsection{Determinants of Financial Fragility}

There are number of factors which could affect the financial fragility of banks. Therefore, along with reforms and regulations indicators, we have also considered both bank-specific and macroeconomic determinants of financial fragility of sample countries. Below is the explanation of the related variables.

\subsection{Financial Reform}

The financial reform variable is based on seven different dimensions. The first six dimensions measure financial liberalization, whereas the seventh dimension measures the strength of bank capital regulation and supervision. The first six dimensions of liberalization are as follows: 1-Credit Allocation Controls and High Reserve Requirement; 2-Interest Rate Liberalization; 3-Entry Barriers; 4-Privatization; 5-Capital Accounts Liberalization; 6-Securities Market Policy. The seventh dimension of financial reform is coded as Banking Prudential Regulation and Supervision. The strength of the first six

5 Hermes et al. [19] also used Abiad et al. [20] index of financial reform variables and found a positive impact of financial reform programme on banking efficiency.

6 Rinaldi's and Sanchis-Arellano's [13] also used ratio of non-performing loans and suggested that it is the best available measure of financial fragility. 
dimensions of liberalization are based on a four-point scale from fully repressed to fully liberalized (0-3), where 0, 1, 2 and 3 are shown as fully repressed, partially liberalized, largely liberalized and fully liberalized, respectively. The intensity of the seventh dimension of financial reform is also captured by a four-point scale (0-3) and is associated with unregulated and unsupervised, less regulated and less supervised, largely regulated and largely supervised and highly regulated and highly supervise, respectively.

Delis [18] used the financial reform variable and found that financial liberalization policies decrease the banks' market power, especially in developed economies. In this paper, we also treated the financial liberalization index and banking regulation and supervision indices separately in the regression, and analyzed their impact on financial fragility.

\subsection{Equity to Assets Ratio}

The equity to assets ratio shows a bank's capability to face any kind of unexpected loss. The higher equity to asset ratio indicates that banks are well-capitalized, which suggests that they become more secure and the chances of bank default decreases. ${ }^{7}$ Demirguc-Kunt and Huizinga [23] also include equity to assets ratio in their study and considered it to represent the banks' moral hazard (which plays an important role in increasing risk to the banking sector), because less capitalized banks are insecure and have a high chance of default, which enhances the moral hazard and risk taking behavior of banks in order to capture increasing short-run profitability, so banks will invest in highly risky asset portfolios for higher profits and put more emphasis on profit and less on risk, which can lead to significant financial crises.

\subsection{Growth of Gross Loan}

The growth of gross loans compares the current year's gross loans as a percentage of the previous years'. Excessive loan growth over-inflation and loan growth in the economy can be a warning sign of deteriorating underwriting standards. ${ }^{8}$ Foos et al. [24] examined the effects of loan growth on the riskiness of banks in 16 countries during the period 1997-2007 and suggested that loan growth is an important factor for bank riskiness. Similarly, Clair [25] examined a data set from banks in Texas during the sample period 1976-1990 and explored the relationship between loan quality (used as proxy of NPLs and charge-off rate) and loan growth rates. He found a negative and significant impact of loan growth on both, the NPLs and charge-off rate in initial years, while finding a positive effect of loan growth on NPLs and charge-off rate in lagged years. We also expect that loan growth leads to an increase of NPLs after one or more years. So, the lagged value of loan growth is included in the regression as a control variable and the expected sign between financial fragility and the lagged of loan growth is positive because of rapid credit growth and a possible decline in loan quality during an economic contraction. Rapid credit growth could deteriorate the ability of banks to monitor borrowers cautiously, thus enhancing the ratio of bad debts (Clair [25]).

7 Delis [18] and Soedarmono et al. [22] also used equity to asset ratio to control for bank capitalisation.

8 See Bank-Scope data definitions. 


\subsection{Total Assets}

To measure the impact of size effects of banks on financial fragility, the natural logarithm of total assets is also included in the model. Demirguc-Kunt and Huizinga [23] also used the logarithm of total assets to measure the absolute size of a bank. The sign of the log of total assets is expected to be negative to financial fragility. The reason could be that big banks are more equipped in risk management strategies, and have enough resources to deal with defaulters, ${ }^{9}$ while Mishkin [26] and Kane [27] documented that the "too big to fail" effect in large size of banks can also be the main reason for higher risk taking.

\subsection{Cost to Income Ratio}

Cost to income ratio (used as a proxy of bank efficiency) is also included as a control variable in the model of financial fragility. This ratio measures the efficiency and overhead of the bank. The lower (higher) the ratio, the better (worse) the efficiency, ${ }^{10}$ which implies that efficient banking system could reduce the probability of loan defaults. Shehzad et al. [6] and Espinoza et al. [9] also used cost to income ratio as a proxy of bank efficiency and found a positive relation with impaired loans to gross loans.

\subsection{Ownership Pattern of Banks}

To analyze the relationship between financial fragility and the ownership pattern of banks, the percentage of government banks and foreign banks is considered in the total banking system. Boudriga et al. $[10,11]$ also used these variables against NPLs in MENA countries. ${ }^{11}$ They found a negative relationship between foreign participation from developed countries and NPLs. Similarly, Boudriga et al. [10,11]; Caprio and Martinez [28] reported that government ownership has a positive and significant relationship with bank fragility. ${ }^{12}$ They also found that likelihood of a banking crisis was high in those countries where more than $50 \%$ of banks' assets were government-owned. However, Barth et al. [30,31] do not find any strong associations between government ownership and NPLs. Consequently, we expect a positive coefficient of government-owned banks and a negative coefficient of foreign-owned banks with financial fragility because foreign banks are more efficient in terms of risk management skills and technology as compared to government banks.

\subsection{Macroeconomic Variables}

Several studies in banking and finance literature have considered macroeconomic variables (such as, GDP growth, inflation, changes in unemployment, real wages and real interest rates) and examined their relation with NPLs. For instance, Salas and Surina [4] used GDP growth rate and found a significantly negative impact on NPLs. Similarly, Fofack [5] reported a negative sign of GDP per capita and also documented that in the recession phase of the economy, coupled with declining per

\footnotetext{
$9 \quad$ See Louzis et al. [7].

10 See Bankscope definitions.

11 They used dummy values as proxy of ownership structure.

12 Hu et al. [29] found a positive linkage between government-owned banks and NPLs in the Taiwanese banking sector.
} 
capita GDP, the possibility of loan default is enhanced. Furthermore, Espinoza and Prasad [9] also explained that real GDP growth has negative and significant impact on NPLs in the GCC banking system. Unfavorable macroeconomic conditions deteriorate the banking sector by enhancing the ratio of impaired loans to gross loans. Rinaldi [13] found positive impact of unemployment on debt due to income uncertainty. Similarly, Louzis [7] also suggested that the probability of default is very high among low income borrowers, because a higher rate of unemployment makes it difficult for borrowers to fulfill their obligations. Therefore, this paper included the real GDP per capita growth, unemployment rate and GDP deflator in a base line model as macroeconomic control variables.

\section{Estimation Framework}

As stated earlier, the main objective of the present study is to investigate links between the financial reforms (and its component) and financial fragility in the banking sector. Moreover, we have also investigated the impact of financial liberalization and the quality of banking regulations and supervision on financial fragility. Here, financial fragility is used as a dependent variable and financial reform as an explanatory variable. Furthermore, we also included the bank-specific and macro-specific control variables in the model. In Equation (1), we introduce financial reforms as the main explanatory variable and analyze its impact on financial fragility. Thus, in order to estimate the financial fragility of banks, we consider the standard model used in empirical studies (see Louzis et al. [7], Merkl and Stolz [32] and Salas and Saurina [4]). A dynamic panel specification is specified in the following model:

$$
\begin{gathered}
F F_{i, j, t}=\beta_{0}+\beta_{1} F F_{i, j,(t-1)}+\beta_{2} Y_{i, j, t}+\alpha_{1}\left(F R_{j, t}\right)+\alpha_{2}\left(F S_{i, j, t}\right)+\alpha_{3}\left(G S_{i, j, t}\right)+\alpha_{4} X_{i, j, t}+\mu_{i, j} \\
+\eta_{t}+\xi_{i, j, t}
\end{gathered}
$$

where " $F F_{i, j, t}$ " is the dependent variable (i.e., financial fragility) of bank " $i$ " in country " $j$ " during time " $t$ " while " $F F_{i, j, t-l}$ " is the lagged value of a dependent variable. "Y $\mathrm{Y}_{i, j, t}$ " denotes the bank-specific variable (which includes bank efficiency, equity to assets ratio, the lagged value of growth of gross loans and $\log$ of total assets), "FR $\mathrm{F}_{j, t}$ " is financial reform (include all the seven dimensions; namely, Credit Allocation Control and High Reserve Requirement, Interest Rate Liberalization, Entry Barriers, Privatization, Capital Accounts Liberalization, Securities Market Policy and Banking Prudential Regulations and Supervision) in country " $j$ " during time $t$, "FS $S_{i, j, t}$ " and "GS $\mathrm{GS}_{i, j, t}$ " represent the share of foreign banks and the share of government banks in the banking sector, respectively; similarly, " $\mathrm{X}_{j, t}$ " indicates the macroeconomic variables (which includes real GDP growth, GDP deflator and unemployment rate), " $\mu_{i, j}$ " are the unobserved individuals specific effects, " $\eta$ " is the time specific effects and " $\xi_{i, j, t}$ " is the error term.

In Equation (2), we have introduced the overall index of financial liberalization (include all the six dimensions; namely, Credit Allocation Control and High Reserve Requirement, Interest Rate Liberalization, Entry Barriers, Privatization, Capital Accounts Liberalization and Securities Market Policy) as an explanatory variable and analyze its impact on financial fragility. In this model, we have replaced the financial reform index by financial liberalization.

$$
\begin{gathered}
F F_{i, j, t}=\beta_{0}+\beta_{1} F F_{i, j,(t-1)}+\beta_{2} Y_{i, j, t}+\beta_{3}\left(F L_{j, t}\right)+\alpha_{2}\left(F S_{i, j, t}\right)+\alpha_{3}\left(G S_{i, j, t}\right)+\alpha_{4} X_{i, j, t}+\mu_{i, j} \\
+\eta_{t}+\xi_{i, j, t}
\end{gathered}
$$


where "FL $j, t$ " indicates financial liberalization in country " $j$ " during the time " $t$ ". Similarly, in Equation (3), we have introduced both the aggregate index of financial liberalization and the banking regulations and supervision index separately, and analyze their impact on financial fragility.

$$
\begin{gathered}
F F_{i, j, t}=\beta_{0}+\beta_{1} F F_{i, j,(t-1)}+\beta_{2} Y_{i, j, t}+\beta_{3}\left(F L_{j, t}\right)+\beta_{4}\left(B R S_{j, t}\right)+\alpha_{2}\left(F S_{i, j, t}\right)+\alpha_{3}\left(G S_{i, j, t}\right) \\
+\alpha_{4} X_{i, j, t}+\mu_{i, j}+\eta_{t}+\xi_{i, j, t}
\end{gathered}
$$

where" $\mathrm{FL}_{j, t}$ " shows financial liberalization and "BRS $\mathrm{B}_{j, t}$ " indicates banking regulations and supervision in country " $j$ " during the time " $t$ ".

To address the potential problem of endogeneity and the possibility of correlation between any right hand side variable of the model with error term $\left(\xi_{i, j, t}\right)$, we used a dynamic two-step system GMM panel estimator of Blundell and Bond [33] with Windmeijer [34] finite sample correction (which provides robust standard errors). We also used Sargan test for the validity of over-identifying restriction in the model and Autocorrelation test of order one and order two (AR-1 and AR-2) for zero or no correlation.

\section{Empirical Results}

The detailed summary of financial fragility and all its bank-specific and macro-specific variables are explained in Table 2 which are used in the empirical analysis. This table shows the units of measurement, mean, standard deviation, minimum and maximum values of these variables. All variables are in percentages (\%) except for the financial reform index. The mean value of the financial fragility in 76 countries is around $9.8 \%{ }^{13}$ and moves from a minimum value of zero to a maximum value $86.9 \%$. The asset quality amongst the lending institutions is extensively measured by NPLs, and often financial crises in both the developed and developing countries are linked with NPLs (Guy and Lowe [3]).The sample mean value of the log of total assets is 6.14 million USD with a minimum and maximum value of 0.129 million USD and 14.12 million USD, respectively. The growth of gross loans is $18.72 \%$ on an average with a standard deviation of $25.89 \%$, and the minimum and maximum percentage of loan growth is $29.8 \%$ and $160.22 \%$ accordingly.

Similarly, the average ratio of equity to assets is around $17.01 \%$, with a minimum value of 0 to a maximum value of $86.98 \%$. The mean value of cost to income ratio is $57 \%$, approximately. Here, the cost to income ratio is used as a proxy for bank efficiency, minimum and maximum value moving between 0 to $100 \%$. Similarly, the mean value of the financial reform index is around 15.71; the minimum index value is 7 and the maximum index value is 21 . The share of government banks and the share of foreign banks in the banking sector is around 5.53\% and $17.35 \%$, respectively; the minimum and maximum shares of government and foreign banks are $0 \%$ and $100 \%$. Beside the bank-specific variables, the mean value of per capita growth rate in these countries is $3.53 \%$; the minimum value of growth rate is $-2.64 \%$ and the maximum value of growth rate is $13.69 \%$. The average rate of the GDP deflator is $5.39 \%$ and ranges from $0.18 \%$ to $14.96 \%$. Lastly, the average unemployment rate is around $9.22 \%$ with minimum and maximum values of $1.3 \%$ and $31.22 \%$.

13 The ratio of impaired loans to gross loans is very high by international standards (see Demetriades and Fielding [35]). 
Table 1. List of countries by financial fragility, financial reforms and by No. of banks.

\begin{tabular}{|c|c|c|c|c|c|c|c|}
\hline Country Name & $\begin{array}{l}\text { No. of } \\
\text { Banks }\end{array}$ & $\begin{array}{l}\text { Financial } \\
\text { Fragility }\end{array}$ & $\begin{array}{c}\text { Financial } \\
\text { Reforms }\end{array}$ & Country Name & $\begin{array}{l}\text { No. of } \\
\text { Banks }\end{array}$ & $\begin{array}{l}\text { Financial } \\
\text { Fragility }\end{array}$ & $\begin{array}{c}\text { Financial } \\
\text { Reform }\end{array}$ \\
\hline Albania & 15 & 5.39 & 15.50 & Korea rep. Of & 121 & 5.55 & 15.00 \\
\hline Algeria & 20 & 6.96 & 11.25 & Kyrgyzstan & 15 & 11.02 & 15.80 \\
\hline Argentina & 163 & 21.96 & 14.60 & Latvia & 29 & 1.74 & 21.00 \\
\hline Azerbaijan & 33 & 6.31 & 13.60 & Lithuania & 15 & 2.13 & 19.05 \\
\hline Bangladesh & 40 & 11.12 & 10.20 & Madagascar & 7 & 7.61 & 16.10 \\
\hline Belarus & 28 & 2.44 & 10.50 & Malaysia & 131 & 15.59 & 16.00 \\
\hline Belgium & 169 & 3.00 & 20.40 & Mexico & 107 & 3.75 & 20.00 \\
\hline Bolivia & 20 & 17.15 & 18.60 & Morocco & 28 & - & 14.00 \\
\hline Brazil & 263 & 11.16 & 11.80 & Mozambique & 17 & 7.05 & 15.00 \\
\hline Bulgaria & 38 & 4.56 & 17.25 & Nepal & 28 & 10.08 & 9.00 \\
\hline Burkina Faso & 10 & 9.30 & 13.00 & Netherlands & 146 & 2.41 & 20.80 \\
\hline Cameroon & 17 & 8.93 & 13.00 & New Zealand & 33 & 0.93 & 20.00 \\
\hline Chile & 44 & 1.47 & 19.00 & Nicaragua & 22 & 7.02 & 15.25 \\
\hline China & 192 & 9.54 & 8.85 & Nigeria & 100 & 18.75 & 17.10 \\
\hline Colombia & 71 & 6.82 & 15.00 & Norway & 175 & 1.46 & 18.25 \\
\hline Costa Rica & 112 & 9.72 & 11.00 & Pakistan & 62 & 12.45 & 11.40 \\
\hline Czech republic & 57 & 12.47 & 19.25 & Paraguay & 29 & 5.28 & 16.50 \\
\hline Denmark & 165 & 1.49 & 21.00 & Peru & 45 & 5.99 & 19.00 \\
\hline Dominican & 60 & 4.33 & 13.45 & Philippines & 83 & 11.24 & 16.20 \\
\hline Ecuador & 48 & 16.34 & 14.80 & Poland & 86 & 13.17 & 17.90 \\
\hline Egypt & 46 & 15.05 & 14.80 & Portugal & 73 & 2.57 & 17.50 \\
\hline El Salvador & 23 & 6.95 & 16.80 & Romania & 45 & 2.68 & 16.90 \\
\hline Estonia & 18 & 2.63 & 21.00 & Senegal & 14 & 4.91 & 14.40 \\
\hline Ethiopia & 14 & 16.41 & 7.80 & Singapore & 111 & 18.23 & 20.00 \\
\hline Finland & 35 & 0.67 & 17.00 & South Africa & 104 & 7.62 & 18.25 \\
\hline Georgia & 20 & 4.23 & 19.05 & Sri Lanka & 22 & 12.00 & 14.00 \\
\hline Ghana & 35 & 17.85 & 11.00 & Taiwan & 128 & 4.90 & 14.15 \\
\hline Greece & 38 & 7.79 & 17.60 & Tanzania & 38 & 10.11 & 16.60 \\
\hline Guatemala & 46 & 6.99 & 15.60 & Thailand & 74 & 11.90 & 13.40 \\
\hline Hungary & 65 & 3.01 & 20.25 & Tunisia & 39 & 24.26 & 14.40 \\
\hline India & 131 & 10.98 & 12.40 & Turkey & 119 & 7.59 & 15.50 \\
\hline Indonesia & 131 & 7.48 & 13.60 & Uganda & 33 & 4.08 & 14.90 \\
\hline Ireland & 97 & 1.02 & 21.00 & Ukraine & 78 & 3.41 & 14.10 \\
\hline Israel & 23 & 7.73 & 18.60 & Uruguay & 58 & 16.10 & 15.20 \\
\hline Jamaica & 22 & 6.35 & 14.80 & Uzbekistan & 19 & 2.74 & 9.30 \\
\hline Jordan & 21 & 17.87 & 19.25 & Venezuela & 90 & 9.25 & 17.45 \\
\hline Kazakhstan & 43 & 4.24 & 13.60 & Vietnam & 54 & 2.80 & 8.90 \\
\hline Kenya & 66 & 19.37 & 14.90 & Zimbabwe & 49 & 13.67 & 12.15 \\
\hline
\end{tabular}

Sources: Bank Scope Data set maintained by Fitch/IBCA/Bureau Van Dijk. A New Database of Financial Reforms by Abiad,

Detragiache and Tressel [20]. 
Table 2. Summary statistics of all variables.

\begin{tabular}{ccccc}
\hline Variable & Mean & Std. Dev. & Min & Max \\
\hline Financial Fragility (\%) & 9.80 & 12.8 & 0 & 86.9 \\
Total Assets Million USD & 6.14 & 2.26 & 0.12 & 14.1 \\
Growth of Gross Loans (\%) & 18.7 & 25.8 & -29.8 & 160.2 \\
Equity to Asset Ratio (\%) & 17.0 & 16.4 & 0 & 86.9 \\
Cost to Income Ratio (\%) & 57.1 & 20.8 & 0 & 100 \\
Financial Reforms & 15.7 & 3.51 & 7 & 21 \\
Share of Foreign banks (\%) & 17.3 & 34.9 & 0 & 100 \\
Share of Govt. banks (\%) & 5.53 & 21.2 & 0 & 100 \\
GDP Per Capita Growth (\%) & 3.53 & 3.02 & -2.64 & 13.6 \\
GDP Deflator (\%) & 5.39 & 3.38 & 0.18 & 14.9 \\
Unemployment (\%) & 9.22 & 5.78 & 1.30 & 31.2 \\
\hline
\end{tabular}

Notes: Table describes the number of observations of the determinants that are used in the model to analyze the financial fragility of sample countries. Financial fragility used as a proxy of impaired loans to gross loans for and cost to income ratio used as proxy for banks efficiency. (Source: Bank Scope Data set maintained by Fitch/IBCA/Bureau Van Dijk).

Table 3 presents the pair-wise correlations matrix of the dependent variable with banks-specific and country-specific variables. The correlation matrix has shown that financial fragility and all explanatory variables are statistically significant at the 5\% level, except the bank's efficiency. It is important to note that correlation between the log of total assets and the growth of gross loans is very high; that is, around $-45 \%$. Similarly, the correlation coefficient of equity to assets ratio, the growth of gross loans and the $\log$ of total assets with financial fragility is $20.2 \%,-20.9 \%$ and $-19.1 \%$, respectively. The pair-wise correlation matrix also explains that the growth of gross loans, the log of total assets, financial reforms, financial liberalization, per capita growth and share of foreign banks are negatively correlated with the financial fragility while the correlation between financial fragility and cost to income ratio, equity to assets ratio, GDP deflator, unemployment and share of government banks is positive.

The dynamic estimation results of financial fragility in sample countries during the sample period are explained in Tables 4-6. The equity to assets ratio and lagged value of financial fragility are treated as an endogenous variable in the models, whereas, the bank efficiency variable is treated as a predetermined variable, meaning that "GMM style" instruments are used. The lagged dependent variable and bank specific variable have instrumented by its lagged value in all regressions. The $p$-value of the Sargan test and AR(2) is somewhat larger than the 5\% level, which suggests that the null hypothesis of over-identification and AR(2) serial correlation cannot be rejected. These diagnostic tests provide evidence of validity of the instruments used. 
Table 3. Pair-wise correlation matrix of all variables.

\begin{tabular}{|c|c|c|c|c|c|c|c|c|c|c|c|c|}
\hline & 1 & 2 & 3 & 4 & 5 & 6 & 7 & 8 & 9 & 10 & 11 & 12 \\
\hline Financial fragility & 1.000 & & & & & & & & & & & \\
\hline Cost to income ratio & $0.013(0.345)$ & 1.000 & & & & & & & & & & \\
\hline Equity to assets ratio & $\begin{array}{c}0.202 * \\
(0.00)\end{array}$ & $\begin{array}{c}-0.061 * \\
(0.00)\end{array}$ & 1.000 & & & & & & & & & \\
\hline Growth of gross loans & $\begin{array}{c}-0.209 * \\
(0.00)\end{array}$ & $\begin{array}{l}0.011 \\
(0.36)\end{array}$ & $\begin{array}{c}-0.025 * \\
(0.038)\end{array}$ & 1.000 & & & & & & & & \\
\hline Log of total assets & $\begin{array}{c}-0.191 * \\
(0.00)\end{array}$ & $\begin{array}{c}-0.182 * \\
(0.00)\end{array}$ & $\begin{array}{c}-0.445 * \\
(0.000)\end{array}$ & $\begin{array}{c}-0.101 * \\
(0.000)\end{array}$ & 1.000 & & & & & & & \\
\hline Financial reforms & $\begin{array}{c}-0.110 * \\
(0.00)\end{array}$ & $\begin{array}{l}0.041 \text { * } \\
(0.00)\end{array}$ & $\begin{array}{c}-0.053 * \\
(0.000)\end{array}$ & $\begin{array}{c}-0.104 * \\
(0.000)\end{array}$ & $\begin{array}{l}0.103 * \\
(0.000)\end{array}$ & 1.000 & & & & & & \\
\hline Financial liberalization & $\begin{array}{c}-0.083 * \\
(0.00)\end{array}$ & $\begin{array}{c}0.054 \text { * } \\
(0.00)\end{array}$ & $\begin{array}{c}-0.038 * \\
(0.000)\end{array}$ & $\begin{array}{c}-0.110 * \\
(0.000)\end{array}$ & $\begin{array}{l}0.078 \text { * } \\
(0.000)\end{array}$ & $\begin{array}{l}0.981 * \\
(0.000)\end{array}$ & 1.000 & & & & & \\
\hline GDP per capita growth & $\begin{array}{c}-0.041 * \\
(0.00)\end{array}$ & $\begin{array}{c}-0.031 * \\
(0.00)\end{array}$ & $\begin{array}{l}0.024 \text { * } \\
(0.021)\end{array}$ & $\begin{array}{l}0.160 * \\
(0.000)\end{array}$ & $\begin{array}{l}0.053 * \\
(0.000)\end{array}$ & $\begin{array}{c}-0.134 * \\
(0.000)\end{array}$ & $\begin{array}{l}-0.161 * \\
(0.000)\end{array}$ & 1.000 & & & & \\
\hline GDP deflator & $\begin{array}{l}0.058 \text { * } \\
(0.00)\end{array}$ & $\begin{array}{l}0.033 * \\
(0.00)\end{array}$ & $\begin{array}{l}0.073 * \\
(0.000)\end{array}$ & $\begin{array}{l}0.120 * \\
(0.000)\end{array}$ & $\begin{array}{c}-0.123 * \\
(0.000)\end{array}$ & $\begin{array}{c}-0.108 * \\
(0.000)\end{array}$ & $\begin{array}{c}-0.097 * \\
(0.000)\end{array}$ & $\begin{array}{c}-0.033 * \\
(0.000)\end{array}$ & 1.000 & & & \\
\hline Unemployment & $\begin{array}{l}0.139 * \\
(0.000)\end{array}$ & $\begin{array}{l}0.039 * \\
(0.001)\end{array}$ & $\begin{array}{l}0.086 * \\
(0.000)\end{array}$ & $\begin{array}{l}-0.025 \\
(0.063)\end{array}$ & $\begin{array}{c}-0.150 * \\
(0.000)\end{array}$ & $\begin{array}{l}0.069 * \\
(0.000)\end{array}$ & $\begin{array}{l}0.077 \text { * } \\
(0.000)\end{array}$ & $\begin{array}{c}-0.018 * \\
(0.014)\end{array}$ & $\begin{array}{l}0.130 * \\
(0.000)\end{array}$ & 1.000 & & \\
\hline Share of foreign banks & $\begin{array}{c}-0.065 * \\
(0.000)\end{array}$ & $\begin{array}{c}0.007 \\
(0.473)\end{array}$ & $\begin{array}{c}-0.022 * \\
(0.027)\end{array}$ & $\begin{array}{l}0.052 * \\
(0.000)\end{array}$ & $\begin{array}{c}-0.025 * \\
(0.010)\end{array}$ & $\begin{array}{l}0.048 * \\
(0.000)\end{array}$ & $\begin{array}{l}0.036 \text { * } \\
(0.000)\end{array}$ & $\begin{array}{l}0.067 \text { * } \\
(0.000)\end{array}$ & $\begin{array}{c}0.002 \\
(0.704)\end{array}$ & $\begin{array}{l}0.031 * \\
(0.000)\end{array}$ & 1.000 & \\
\hline Share of govt. banks & $\begin{array}{l}0.093 * \\
(0.000) \\
\end{array}$ & $\begin{array}{c}-0.063 * \\
(0.000)\end{array}$ & $\begin{array}{l}-0.068^{*} \\
(0.000) \\
\end{array}$ & $\begin{array}{c}-0.070 * \\
(0.000)\end{array}$ & $\begin{array}{l}0.225 * \\
(0.000) \\
\end{array}$ & $\begin{array}{c}-0.081 * \\
(0.000)\end{array}$ & $\begin{array}{c}-0.078 * \\
(0.000)\end{array}$ & $\begin{array}{l}0.013 * \\
(0.047)\end{array}$ & $\begin{array}{l}-0.006 \\
(0.387)\end{array}$ & $\begin{array}{l}0.034 * \\
(0.000)\end{array}$ & $\begin{array}{c}-0.108 * \\
(0.000)\end{array}$ & 1.000 \\
\hline
\end{tabular}


Tables 4 and 5 contain the main results of the econometric investigation for the whole sample, regardless of the level of banking regulation and supervision quality. Table 4 reports the results of Model 1, in which financial fragility has been regressed on financial reforms, bank-specific (equity to assets ratio, bank efficiency, log of total assets, lagged value of growth of gross loans and share of foreign and government banks) and macro-specific (per capita growth, GDP deflator and unemployment rate) variables. The lagged dependent variable is positive and highly significant at $1 \%$ level in all regressions of Table 4, which confirms the selection and underlines the appropriateness of the dynamic panel model and explains that financial weakness in previous year is likely to exacerbate the current year financial fragility.

The results of Equation (1) are described in Table 4. In Column (1), the equity to assets ratio and $\log$ of total assets obtains coefficients which are negative and significant at the $5 \%$ and $10 \%$ level, respectively; implying that $1 \%$ increase in bank capital stock and big size of banks reduces the chance of financial fragility by -0.17 and -1.06 percentage points, respectively.

Table 4. Dynamic panel estimation of financial fragility with financial reform.

\begin{tabular}{ccccc}
\hline & $\mathbf{( 1 )}$ & $\mathbf{( 2 )}$ & $\mathbf{( 3 )}$ & $\mathbf{( 4 )}$ \\
\hline Financial fragility $(\mathrm{t}-1)$ & $0.692 * * *(0.097)$ & $0.584 * * *(0.108)$ & $0.698 * * *(0.094)$ & $0.582 * * *(0.108)$ \\
Cost to income ratio & $0.096(0.117)$ & $0.012(0.096)$ & $0.101(0.114)$ & $0.017(0.099)$ \\
Equity to assets ratio & $-0.170 * *(0.084)$ & $-0.063(0.096)$ & $-0.194 * *(0.084)$ & $-0.059(0.099)$ \\
Growth of gross loans $(\mathrm{t}-1)$ & $0.033 * * *(0.009)$ & $0.025 * * *(0.010)$ & $0.033 * * *(0.010)$ & $0.025 * * *(0.010)$ \\
Log of total assets & $-1.064 *(0.649)$ & $0.820(1.193)$ & $-1.241 *(0.702)$ & $0.885(1.264)$ \\
Financial reform & $0.309 *(0.168)$ & $0.133(0.160)$ & $0.299 *(0.169)$ & $0.137(0.164)$ \\
GDP per capita growth & $-0.012(0.138)$ & $0.081(0.133)$ & $-0.005(0.145)$ & $0.077(0.137)$ \\
GDP deflator & $-0.053(0.066)$ & $0.055(0.076)$ & $-0.048(0.068)$ & $0.055(0.076)$ \\
Unemployment & $0.246 *(0.143)$ & $0.374 * *(0.177)$ & $0.227 *(0.139)$ & $0.374 * *(0.176)$ \\
Share of foreign banks & - & $-0.404 * *(0.179)$ & - & $-0.413 * * *(0.177)$ \\
Share of govt. banks & - & - & $0.110(0.131)$ & $-0.021(0.152)$ \\
No. of obs. & 1586 & 1586 & 1586 & 1586 \\
No. of Instruments & 33 & 33 & 33 & 33 \\
Wald Chi square $(p$-value $)$ & $145.3 * * *(0.00)$ & $145.1 * * *(0.00)$ & $146.3 * * *(0.00)$ & $149.9 * * *(0.00)$ \\
Sargan test $(p$-value) & $22.77(0.24)$ & $11.55(0.86)$ & $21.13(0.27)$ & $11.58(0.82)$ \\
AR(1) test $(p$-value) & $-2.58 * * *(0.00)$ & $-2.03 * *(0.04)$ & $-2.62 * * *(0.00)$ & $-2.05 * *(0.04)$ \\
AR(2) test $(p$-value) & $1.34(0.17)$ & $1.26(0.20)$ & $1.36(0.17)$ & $1.25(0.21)$ \\
\hline
\end{tabular}

Note: The dependent variable is financial fragility, which is considered as a proxy of impaired loans to gross loans. Equity to assets ratio and lagged value of impaired loans to gross loans are treated as endogenous. The lagged dependent variable is instrumented by its lagged value. Cost to income ratio treated as predetermine variable and instrumented by its lagged value. All regressions include a full set of time dummies but results are not reported in the table. Figures in parenthesis are robust standard errors obtained by the Windmeijer WC-robust estimator. $(* * *)$ Coefficients are statistically significant at the $1 \%$ level. (**) Coefficients are statistically significant at the $5 \%$ level. (*) Coefficients are statistically significant at the $10 \%$ level.

The inverse relationship between equity to assets ratio and financial fragility suggest that less capitalized banks are unsecured with high chance of default, which enhances the moral hazard and risk taking behavior of banks in order to capture the larger market; thus, banks will invest in highly risky assets portfolios for higher profits and put more emphasis on profit and less on risk which leads 
toward high financial vulnerability. The result of the log of total assets is also consistent with Salas and Saurina [4] who found a negative relation between bank size and NPLs, and suggested that bigger banks provide more diversification opportunities, which reduces credit risk. The coefficient of growth of gross loans (gglt-1) is positive and significant at the $1 \%$ conventional level, which implies that high growth of loans in the previous year also enhances the financial fragility (see Espinoza and Prasad [9]), whereas, financial reforms and unemployment are positive and significant at the $10 \%$ levels. Louzis et al. [7] also found a positive and significant impact of unemployment on NPLs in Greece. This could suggest that $1 \%$ increases in loan growth, financial reforms and unemployment enhances financial fragility by $0.03,0.30$ and 0.24 percentage points, while bank efficiency, per capita growth and GDP deflator do not have a significant impact on financial fragility. The results of the log of total assets and loan growth are also consistent with the findings of Salas and Saurian [4] and Fernandez de Lis et al. [36].

The inclusion of the share of foreign banks' variable in Table 4 Column (2) eliminates the significant impact of equity to assets ratio, the log of total assets and financial reforms on financial fragility. Adding the share of government banks' variable in the model in Column (3) does not change the results of the baseline model. The results in Column (2) and (4) also show that the share of foreign banks have a negative and statistically significant impact on financial fragility at the $5 \%$ and $1 \%$ level, respectively, which implies that strict control (due to a more restricted regulatory structure), technological advancement and the efficient financial system in foreign banks reduce financial fragility and enhance banking system stability. This result is consistent with findings of Barth et al. [30,31], who also found a negative relationship between the share of foreign banks and NPLs, whereas, the share of government banks have a positive but insignificant impact on fragility; the plausible justification of this finding could be weaker credit recovery ability.

In Table 5, the dependent variable, the financial fragility, is regressed on the overall index of financial liberalization. The results show that the sign of variables remain unchanged but the coefficients are three times larger than the coefficients of Table 4. Therefore, these findings support the view that in absence of the banking regulations and supervision, financial liberalization raises financial fragility with a higher rate. This result is consistent with the findings of Demirguc-Kunt and Detragiache [16,17], who also suggested that financial liberalization enhances the probability of banking crisis.

The results of Equation (3) are reported in Table 6; financial fragility is regressed against the banking regulations and supervision index separately, with the overall index of liberalization. In Column (1)-(4), the lagged value of the dependent variable and the lagged value of loan growth have a positive and significant impact on financial fragility at the $1 \%$ conventional level, whereas unemployment is significant at the 5\% level.

Similarly, the result in Columns (1) to (4) also shows that banking regulation and supervision has a negative (as expected) impact on financial fragility. Barth, Caprio and Levine [30] also documented that strong regulation reduces the likelihood of NPLs. These results suggest that financial fragility in both the developed and developing countries could be reduced by sound and efficient banking supervision and regulations. The extent of market capitalization (equity to assets ratio) and the greater size of a financial institution (the log of total assets) could significantly reduce the incidence of financial fragility at the $10 \%$ level. 
It is important to note that the relationship of financial liberalization with financial fragility is positive and significant, which implies that financial vulnerability increases in a weak banking environment because banks' regulators and supervisors are less capable of visioning better risk assessment, have less skill in screening and fail to improve banks' efficiency, stability and performance (Barth et al. [30]). These results suggest that regulators and supervisors have a low level of ability to screen and are unable to perform better risk assessment as well as fail to promote banks stability and efficiency. In Column (2)-(4), the relationship between financial fragility and the share of foreign banks is still negative and significant at 5\%. Furthermore, the result of Column (3) shows that the share of government banks has a positive impact on financial fragility. These findings suggest that as the share of government banks increases, the financial system becomes more fragile, especially, in the developing countries.

Table 5. Dynamic panel estimation of financial fragility with financial liberalization.

\begin{tabular}{ccccc}
\hline & $\mathbf{( 1 )}$ & $\mathbf{( 2 )}$ & $\mathbf{( 3 )}$ & $\mathbf{( 4 )}$ \\
\hline Financial fragility (t-1) & $0.684 * *(0.096)$ & $0.586 * * *(0.107)$ & $0.691 * * *(0.094)$ & $0.584 * * *(0.108)$ \\
Cost to income ratio & $0.098(0.118)$ & $0.012(0.097)$ & $0.105(0.115)$ & $0.016(0.100)$ \\
Equity to assets ratio & $-0.167 * *(0.084)$ & $-0.065(0.096)$ & $-0.192 * *(0.084)$ & $-0.063(0.099)$ \\
Growth of gross loans $(\mathrm{t}-1)$ & $0.032 * * *(0.009)$ & $0.025 * * *(0.010)$ & $0.033 * * *(0.010)$ & $0.025 * * *(0.010)$ \\
Log of total assets & $-1.042 *(0.650)$ & $0.818(1.196)$ & $-1.225 *(0.704)$ & $0.854(1.273)$ \\
Financial liberalization & $0.969 * *(0.521)$ & $0.554(0.480)$ & $0.957 *(0.523)$ & $0.561(0.492)$ \\
GDP per capita growth & $-0.013(0.139)$ & $0.080(0.133)$ & $-0.006(0.145)$ & $0.077(0.137)$ \\
GDP deflator & $-0.050(0.067)$ & $0.055(0.077)$ & $-0.046(0.068)$ & $0.055(0.077)$ \\
Unemployment & $0.246 *(0.143)$ & $0.369 * *(0.178)$ & $0.224 *(0.138)$ & $0.369 * *(0.177)$ \\
Share of foreign banks & - & $-0.398 * *(0.179)$ & - & $-0.403 * *(0.178)$ \\
Share of govt. banks & - & - & $0.114(0.130)$ & $-0.015(0.153)$ \\
No. of obs. & 1586 & 1586 & 1586 & 1586 \\
No. of Instruments & 33 & 33 & 33 & 33 \\
Wald Chi square $(p$-value $)$ & $147.9 * * *(0.00)$ & $150.1 * * *(0.00)$ & $149.3 * * *(0.00)$ & $154.4 * * *(0.00)$ \\
Sargan test $(p$-value) & $22.61(0.25)$ & $11.64(0.86)$ & $20.84(0.28)$ & $11.68(0.81)$ \\
AR(1) test $(p$-value) & $-2.56 * * *(0.01)$ & $-2.04 * *(0.04)$ & $-2.59 * * *(0.00)$ & $-2.05 * *(0.03)$ \\
AR(2) test $(p$-value) & $1.34(0.17)$ & $1.27(0.20)$ & $1.36(0.17)$ & $1.26(0.20)$ \\
\hline
\end{tabular}

Note: The dependent variable is financial fragility, which is considered as a proxy of impaired loans to gross loans. Equity to assets ratio and lagged value of impaired loans to gross loans are treated as endogenous. The lagged dependent variable is instrumented by its lagged value. Cost to income ratio treated as predetermine variable and instrumented by its lagged value. All regressions include a full set of time dummies but results are not reported in the table. Figures in parenthesis are robust standard errors obtained by the Windmeijer WC-robust estimator. (***) Coefficients are statistically significant at the $1 \%$ level. $(* *)$ Coefficients are statistically significant at the $5 \%$ level. $(*)$ Coefficients are statistically significant at the $10 \%$ level. 
Table 6. Dynamic panel estimation of financial fragility with financial liberalization and banking supervision.

\begin{tabular}{ccccc}
\hline & $\mathbf{( 1 )}$ & $\mathbf{( 2 )}$ & $\mathbf{( 3 )}$ & $\mathbf{( 4 )}$ \\
\hline Financial fragility(t-1) & $0.676 * *(0.107)$ & $0.575 * * *(0.115)$ & $0.676 * *(0.104)$ & $0.575 * * *(0.115)$ \\
Cost to income ratio & $0.093(0.114)$ & $0.015(0.098)$ & $0.096(0.110)$ & $0.017(0.103)$ \\
Equity to assets ratio & $-0.162 *(0.086)$ & $-0.064(0.099)$ & $-0.184 * *(0.084)$ & $-0.065(0.101)$ \\
Growth of gross loans $(\mathrm{t}-1)$ & $0.032 * *(0.009)$ & $0.024 * * *(0.010)$ & $0.033 * * *(0.010)$ & $0.024 * * *(0.010)$ \\
Log of total assets & $-1.041 *(0.647)$ & $0.818(1.230)$ & $-1.236 *(0.699)$ & $0.797(1.305)$ \\
Financial liberalization & $0.965 *(0.527)$ & $0.507(0.503)$ & $0.922 *(0.530)$ & $0.509(0.518)$ \\
Banking Supervision & $-0.105(1.362)$ & $-0.912(1.402)$ & $-0.433(1.436)$ & $-0.893(1.426)$ \\
Per capita growth & $-0.007(0.137)$ & $0.083(0.134)$ & $0.005(0.144)$ & $0.081(0.140)$ \\
GDP deflator & $-0.044(0.067)$ & $0.060(0.081)$ & $-0.034(0.070)$ & $0.059(0.082)$ \\
Unemployment & $0.249 *(0.142)$ & $0.375 * *(0.179)$ & $0.230 *(0.136)$ & $0.374 * *(0.179)$ \\
Share of foreign banks & - & $-0.388 * *(0.178)$ & - & $-0.387 * *(0.177)$ \\
Share of govt. banks & - & - & $0.128(0.140)$ & $-0.001(0.157)$ \\
No. of obs. & 1586 & 1586 & 1586 & 1586 \\
No. of Instruments & 34 & 34 & 34 & 34 \\
Wald Chi square $(p$-value $)$ & $149.6 * * *(0.00)$ & $146.7 * * *(0.00)$ & $151.4 * * *(0.00)$ & $150.1 * * *(0.00)$ \\
Sargan test $(p$-value) & $22.82(0.24)$ & $11.46(0.87)$ & $20.96(0.28)$ & $11.52(0.82)$ \\
AR(1) test $(p$-value) & $-2.47 * * *(0.01)$ & $-1.95 * *(0.05)$ & $-2.45 * *(0.01)$ & $-1.96 * *(0.05)$ \\
AR(2) test $(p$-value) & $1.33(0.18)$ & $1.25(0.20)$ & $1.35(0.17)$ & $1.25(0.21)$ \\
\hline
\end{tabular}

Note: The dependent variable is financial fragility, which is considered as a proxy of impaired loans to gross loans. Equity to assets ratio and lagged value of impaired loans to gross loans are treated as endogenous. The lagged dependent variable is instrumented by its lagged value. Cost to income ratio treated as predetermine variable and instrumented by its lagged value. All regressions include a full set of time dummies but results are not reported in the table. Figures in parenthesis are robust standard errors obtained by the Windmeijer WC-robust estimator. $(* * *)$ Coefficients are statistically significant at the $1 \%$ level. (**) Coefficients are statistically significant at the $5 \%$ level. (*) Coefficients are statistically significant at the $10 \%$ level.

\section{Conclusions}

It has largely been accepted that over the past few years or so, increasing competition, technological improvement, the development of financial products and increasing liberalization have become a significant challenge in safeguarding the financial stability of the international financial system. The recent waves of banking crises have been mainly attributed to a high ratio of loan defaults. The purpose of this study is to explore the impact of financial reform policies on financial fragility.

This study investigated the determinants of financial fragility for 76 developed and emerging countries by using bank-level data (was obtained from the Bank-scope database maintained by Fitch/IBCA/Bureau Van Dijk) for a sample of 779 banks during the period 2001-2005. We have found that the financial vulnerability of the banking sector can be affected not only by bank-specific and macro-specific variables, but also by financial liberalization and banking regulation and supervision policies. It has also examined the influence of financial reforms, financial liberalization and the quality of banking regulations and the supervision of financial fragility. Moreover, we have also explored the relationship of the financial liberalization index and banking regulations and supervision index on financial fragility individually. The empirical findings of the present study confirm the evidence that 
financial reforms and financial liberalization significantly enhance the likelihood of financial fragility, while strong and sound banking regulations and supervision have an inverse relationship with financial fragility. Consequently, in a weak regulatory and supervisory environment, the financial liberalization may not have as significant impact on financial fragility. These findings suggest that the benefits of financial liberalization can be achieved without the cost of financial fragility if strong and effective banking regulations and supervision are in place. Thus, these findings confirm that financial reforms and financial liberalization are the main factors in terms of enhancing banking sector vulnerability, where financial systems are not fully established and are not well-functioning.

\section{Appendix}

Table A1. Mean value of financial fragility in sample countries during period from 2001 to 2005.

\begin{tabular}{cc}
\hline Year & Impaired Loans (NPLs)/Gross Loans \\
\hline 2001 & 14.19846 \\
2002 & 12.63699 \\
2003 & 10.60693 \\
2004 & 8.31966 \\
2005 & 6.769603 \\
\hline
\end{tabular}

\section{Conflicts of Interest}

The author declares no conflict of interest.

\section{References}

1. Koutsomanoli-Filippaki, A.; Mamatzakis, E. Performance and Merton-Type Default Risk of Listed Banks in the EU: A Panel VAR Approach. J. Bank. Finance 2009, 33, 2050-2061.

2. Moshirian, F. Globalisation, Growth and Institutions. J. Bank. Finance 2008, 32, 472-479.

3. Guy, K.; Lowe, S. Nonperforming Loans And Bank Stability in Barbados. Econ. Rev. 2011, 37, 77-99.

4. Salas, V.; Saurina, J. Credit Risk in Two Institutional Regimes: Spanish Commercial and Saving Banks. J. Financ. Serv. Res. 2002, 22, 203-224.

5. Fofack, H. Nonperforming Loans in Sub-Saharan Africa: Causal Analysis and Macroeconomic Implications; World Bank Policy Research Working Paper No. 3769; World Bank: Washington, DC, USA, 2005. Available online: Http://Ssrn.Com/Abstract=849405 (accessed on 16 November 2005).

6. Shehzad, C.T.; de Haan, J.; Scholtens, B. The Impact of Bank Ownership Concentration on Impaired Loans and Capital Adequacy. J. Bank. Finance 2010, 34, 399-408.

7. Louzis, D.P.; Vouldis, A.T.; Metaxas, V.L. Macroeconomic and Bank-Specific Determinants of Non-Performing Loans in Greece: A Comparative Study of Mortgage, Business and Consumer Loan Portfolios. J. Bank. Finance 2012, 36, 1012-1027.

8. Festić, M.; Kavkler, A.; Repina, S. The Macroeconomic Sources of Systemic Risk in the Banking Sectors of Five New EU Member States. J. Bank. Finance 2011, 35, 310-322. 
9. Espinoza, R.A.; Prasad, A. Nonperforming Loans in the GCC Banking System and Their Macroeconomic Effects; IMF Working Papers no. WP/10/224; International Monetary Fund: Washington, DC, USA, 2010; pp. 1-24. Available online: Http://Ssrn.Com/Abstract=1750712 (accessed on 1 February 2011).

10. Boudriga, A.; Taktak, N.B.; Jellouli, S. Bank Specific, Business and Institutional Environment Determinants of Banks Nonperforming Loans: Evidence from Mena Countries; Economic Research Forum Working Paper No. 547; Economic Research Forum: Cairo, Egypt, 2010.

11. Boudriga, A.; Taktak, N.B.; Jellouli, S. Bank supervision and nonperforming loans: A cross-country analysis. J. Financ. Econ. Policy 2010, 1, 286-318.

12. Berger, T.O.; Boye, K.G. An Analysis of Bank's Problem Loans. Nor. Bank Econ. Bull. 2007, 78, 65-76.

13. Rinaldi, L.; Sanchis-Arellano, A. Household Debt Sustainability: What Explains Household Non-Performing Loans? An Empirical Analysis; ECB Working Paper No. 570; European Central Bank: Franfurt am Main, Germany, 2006. Available online: Http://Ssrn.Com/Abstract=872528 (accessed on 4 January 2006).

14. Ranjan, R.; Dhal, S.C. Non-Performing Loans and Terms of Credit of Public Sector Banks in India: An Empirical Assessment; Reserve Bank of India Occasional Papers: Mumbai, India, 2003; Volume 24, pp. 81-121.

15. Shen, C.; Chen, C. Causality between Banking and Currency Fragilities: A Dynamic Panel Model. Glob. Finance J. 2008, 19, 85-101.

16. Demirguc-Kunt, A.; Detragiache, E. Financial Liberalization and Financial Fragility; IMF Working Paper No. WP/98/83; International Monetary Fund: Washington, DC, USA, 1998.

17. Demirgüç-Kunt, A.; Detragiache, E. The Determinants of Banking Crises in Developing and Developed Countries. Palgrave Macmillan J. 1998, 45, 81-109.

18. Delis, M.D. Bank Competition, Financial Reform, and Institutions: The Importance Being Developed. J. Dev. Econ. 2012, 97, 450-465.

19. Hermes, N.; Meesters, A.; Shehzad, T. Financial Reform and Bank Efficiency: A Multi-Country Analysis. Available online: Http://Ssrn.Com/Abstract=1344624 (accessed on 23 August 2010).

20. Abiad, A.; Detragiache, E.; Tressel, T. A New Database of Financial Reforms; IMF Staff Papers; International Monetary Fund: Washington, DC, USA, 2010; Volume 57, pp. 281-302.

21. Lagunoff, R.; Schreft, S.L. A Model of Financial Fragility. J. Econ. Theory 2001, 99, 220-264.

22. Soedarmono, W.; Machrouh, F.; Tarazi, A. Bank Market Power, Economic Growth and Financial Stability: Evidence from Asian Banks. J. Asian Econ. 2011, 22, 460-470.

23. Demirguc-Kunt, A.; Huizinga, H. Do We Need Big Banks? Evidence on Performance, Strategy and Market Discipline. J. Financ. Intermed. 2013, 22, 532-558.

24. Foos, D.; Norden, L.; Weber, M. Loan Growth and Riskiness of Banks. J. Bank. Finance 2010, 34, 2929-2940.

25. Clair, R.T. Loan Growth and Loan Quality: Some Preliminary Evidence from Texas Banks. Econ. Financ. Policy Rev. 1992, 3, 9-22.

26. Mishkin, F.S. How Big a Problem Is Too Big to Fail? A Review of Gary Stern and Ron Feldman's “Too Big to Fail: The Hazards of Bank Bailouts”. J. Econ. Lit. 2006, 44, 988-1004. 
27. Kane, E.J. Incentives For Banking Mega Mergers: What Motives Might Regulators Infer from Event-Study Evidence? Part 2: What Should Central Banks Do? J. Money Credit Bank. 2000, 32, 671-701.

28. Caprio, G.; Martinez Peria, M.S. Avoiding Disaster: Policies to Reduce the Risk of Banking Crises; Working Paper No. 47; Egyptian Centre for Economic Studies: Cairo, Egypt, 2000.

29. Hu, J.; Li, Y.; Chiu, Y. Ownership and Nonperforming Loans: Evidence from Taiwan's Banks. Dev. Econ. 2004, 42, 405-420.

30. Barth, J.R.; Caprio, G., Jr.; Levine, R. Bank Regulation and Supervision: What Works Best? J. Financ. Int. 2004, 13, 205-248.

31. Barth, J.R.; Dopico, L.G.; Nolle, D.E.; Wilcox, J.A. Bank Safety and Soundness and the Structure of Bank Supervision: A Cross-Country Analysis. Int. Rev. Finance 2002, 3, 163-188.

32. Merkl, C.; Stolz, S. Banks' Regulatory Buffers, Liquidity Networks and Monetary Policy Transmission. Appl. Econ. 2009, 41, 2013-2024.

33. Blundell, R.; Bond, S. Initial Conditions and Moment Restrictions in Dynamic Panel Data Models. J. Econom. 1998, 87, 115-143.

34. Windmeijer, F. A Finite Sample Correction for the Variance of Linear Efficient Two-Step GMM Estimators. J. Econom. 2005, 126, 25-51.

35. Demetriades, P.O.; Fielding, D. Information, Institutions and Banking Sector Development in West Africa. Econ. Inq. 2012, 50, 739-753.

36. De Lis, F.S.; Pages, J.M.; Saurina, J. Credit Growth, Problem Loans and Credit Risk Provisioning in Spain; Banco de Espana Working Papers No. 18; Banco de Espana: Madrid, Spain, 2000.

(C) 2015 by the author; licensee MDPI, Basel, Switzerland. This article is an open access article distributed under the terms and conditions of the Creative Commons Attribution license (http://creativecommons.org/licenses/by/4.0/). 